\title{
AGGRESSIVE BEHAVIOUR AND BULLYING AS MOST FREQUENT EDUCATIONAL PROBLEMS AT SCHOOLS AND POSSIBILITIES OF PREVENTION
}

\author{
Katarína Cimprichová Gežová
}

\begin{abstract}
At primary and also secondary schools we are facing more and more often psychological and physical attacks on pupils and teachers. It includes various insults, fights among pupils, ridicule, destruction of school property or personal objects of pupils and teachers. The behaviour of such individuals is influenced by several factors: negative family environment, inadequate spending of leisure time, influence of peer groups and influence of media - television, Internet. Children often witness aggressive behaviour in their families and consider it a natural part of life and they often adopt the incorrect behavioural patterns of their parents. The behaviour of individuals is also influenced by changes that have taken place in our society over the last decades (unemployment, rising divorce rate, criminality, drug addiction and other socio-pathological phenomena). The rising brutality and lower age of attackers and aggressors is an alarming fact for our society. That is the reason why various disciplines such as pedagogy, psychology, sociology, criminology and others, deal with these issues. Our goal is to point out the aggressive behaviour, bullying and prevention of these socio-pathological phenomena by pupils at schools.
\end{abstract}

\section{Keywords}

aggressive behaviour, bullying, educational problems, school, prevention

\section{Introduction}

The problems of aggressive behaviour and bullying are nowadays very topical and we can say that they belong to the most frequent educational problems at schools. The causes of emergence of these educational difficulties can be found, on the one hand, in 
the economic and material family situation, because the living standards are constantly rising which causes the inability of a family to secure the basic needs of its members, lack of interest towards the upbringing of children, lack of free time spent with children that are often consequently raised "by the street". Such problematic behaviour and consequent educational problems endanger mainly children from socially disadvantaged backgrounds. We can definitely claim that children's behaviour depends in the first place on the education in the family and subsequently in schools. Family is the basis and the school should build on it. If children do not have this necessary basis, it often comes to problems. The fact that there is no society-wide system of prevention in Slovakia, also contributes to the emergence of these problems. Prevention in a school environment should work against the increase in problematic behaviour of pupils, educational problems, emergence of aggressive behaviour and bullying. Aggressiveness and bullying give rise to tension, conflicts and a negative atmosphere in a social group or classroom. The term aggressive behaviour has become relatively often used in our society, be it the aggressive behaviour of individuals or of the whole group. According to Erkert (2004, p. 7) "aggressiveness is a spontaneous characteristic of a person that serve as means of survival in unfavourable and life-threatening situations. When uncontrolled, it can show up in the form of instinctive aggressive behaviour. Long-term repetition develops into a form of a stabilized behavioural pattern. In this case, it loses the necessary positive function in social context. In the area of pedagogy, outbursts of anger that are aimed at other people or at one's own person or things are classified as "aggressiveness". Yelling, threats, beating, biting, spitting, scratching, kicking are examples of children's reactions to common impulses. This uncontrolled behaviour raises a certain fear especially by younger, weaker and unassertive individuals that are directly or indirectly exposed to it." This kind of behaviour has several forms. It occurs mostly as physical and psychological abuse, violent acts, blackmailing, destroying someone's own or somebody else's property. Aggressiveness of children and young people in a school environment towards themselves or even teachers is increasing. Through such behaviour it comes to restriction and violation of human rights that influence the whole society and so the overall personality development of individuals. According to Emmerová (2011) it is a real or symbolic restriction and violation of rights of other people, destruction and damage. Aggressive behaviour is complex, multicausal and can definitely be classified as a socio-pathological phenomenon. Nowadays, the term aggressiveness is understood as aggressiveness, hostility or belligerence in acting towards a certain object. It is also understood as an attack on hindrance - person or object, on the way to satisfy one's needs (Janderková, 2010). Lovaš (2010) distinguishes between aggressiveness and aggression, in that aggressiveness does not necessarily manifest itself in the behaviour and aggression is an act that is carried out or behaviour that leads to hurting.

Bullying is an inseparable part of aggressiveness. It is a non-traditional asymmetric type of aggression and we can consider it specific manifestation of aggression that can have various causes, forms and psychological backgrounds. Bullying is a serious problem 
that attracts the attention of experts and of a non-professional public. It occurs in different places, in families, at schools, in school and after-school facilities, at work etc. Its occurrence at schools is serious because it results in many negative phenomena, such as bad school results, truancy, aggressiveness, thefts, suicide and many others. The French term for bullying is "chicane" which means malicious intentionally repeated humiliation, victimization, bothering, abuse and attack of another person. It is a form of pathological behaviour with elements of aggression and manipulation in that it comes to disproportion of powers between the aggressor and the victim. Bullying is not a relation between individuals but a consequence of disturbance of relationships in a group (Tinka, 2010). Emmerová (2013) classifies bullying at schools as pathological behaviour which is an extreme form of aggressive behaviour. It occurs mostly during the breaks, in places without the supervision of a pedagogue, on toilets and in changing rooms. It can also occur on the way to school or home. Legally, bullying is considered a violent crime committed by a child, an adolescent or an adult. In the case of an underage person, the bullying can be classified as juvenile delinquency (Šimegová, 2007).

\section{Aggressiveness and bullying as behavioural disorders in a school environment}

People living in society must follow certain rules that have their defined sphere of activity. They complement, mingle, determine one another and have their hierarchy. In case one of them is disturbed, it comes to a chain reaction and launching of many disorders (Kunák, 2007, p. 9-10). Behavioural disorders and the cause of emergence thereof are ambiguous. Some experts speak about different influences that participate in the emergence of behavioural disorders. In the international classification (Kariková, 2001, p. 86) the behavioural disorders are described as repeated and permanent patterns of dissocial, aggressive and defiant behaviour in that the individual breaks age-appropriate social norms and expectations (e.g. lies, fights, thefts, running away from home, cruelty to animals and people, truancy and others). We understand the term behavioural disorder as "such individual's manifestations that are deviating from ordinary behaviour of given age and socio-cultural group". Kariková (2001, p. 87) distinguishes two basic forms of psychosocial problems:

1. Passive form - various escape reactions such as truancy, absences, avoiding of company, up to the extreme form - suicide. We speak of negative breaking of social norms (lies, escapes, thefts, truancy) and these are usually described as less serious, although they can lead to committing crimes.

2. Aggressive form - it manifests itself in committing crimes and delinquency (bullying, vandalism, attacks etc.). Aggressive behaviour breaks and restricts the rights of other people; therefore we describe these as serious behavioural disorders that can be connected with committing crimes. 
According to Miňhová and Mrázová (1989, p. 59-60) we distinguish three basic forms of problematic behaviour:

1. dissocial behaviour,

2. asocial behaviour,

3. antisocial behaviour.

They consider dissocial behaviour the least socially serious (defective) and it is often connected with age peculiarities (pubescent negativism). They are short-term excesses in behaviour of individuals. The authors consider asocial behaviour socially more serious but by this form of behaviour it does not come to disturbance of social values. The individual harms mainly himself (truancy, alcoholism, drug addiction, self-harm etc.). Antisocial behaviour means that the individual harms the society intentionally with the purpose to hurt. Legally, it includes offences, misdemeanours and crimes characterized by various degrees of aggressiveness and are aimed against property, people and social values in general (assault and battery, theft, vandalism, rape, murder). According to Emmerová (2011, p. 26) there are various causes of emergence of problematic behaviour and these can generally be divided into internal and external causes. Internal causes include inherited predispositions, psychological factors etc. The external factors include family environment, peers, mass media, school and social relationships in a classroom. Nowadays, there are three basic theories that explain the arising and development of aggression and aggressive behaviour by people:

1. Theory of inherited inclination - it includes two subtheories - psychoanalytic and ethological theory. Both of them claim that there is an instinctive basis and instinctive energy in aggression that is natural for all living beings. Ethologists assume that there are specific triggers of aggression that are inherited.

2. Reactive theory - describes aggression as a response to frustration, anxiety, hindrances to achieve a goal, as response to a state of danger or emergency. It emphasizes external factors.

3. Theory of social learning - points out the aggression as a certain learned form of social behaviour (influence of education, social learning and culture) (Hroncová, Emmerová, \& Hronec, 2014, p. 120).

Határ (2007, p. 32-33) describes five perspectives of children's and adolescent aggression as defined by German pedagogue M. Winkel:

1. aggression as a form of a game - child's aim is to test the range of his strength,

2. aggression as a defence mechanism - the victims defend themselves against the attacker,

3. aggression as a reaction of a frustrated individual - child looks for a substitution for his loss/defeat via weaker individuals, it is a certain inferiority complex of the aggressor,

4. aggression as a form of curiosity - child wants to find out where his limits are,

5. aggression as an inappropriate form of desire for love - child tries to catch the attention through negative behaviour. 
There are different reasons why children and young people try to solve their conflicts via aggressive behaviour. Aggressive behaviour is, apart from watching media violence, also influenced by physical and mental neglect that can show in all social strata. But it would be too simple to attach the undesirable ways of children's behaviour only to family background. First of all, we should turn our attention to the society that, on the one hand, complains about rising aggressiveness but on the other hand, is less active in building playgrounds and supporting of leisure activities. Mainly children growing up in towns and cities can find fewer green areas that would enable undisturbed and safe outside games and therefore they spend a lot of time closed inside their flats. It is only a matter of time when the child's inner emptiness would grow so big that first signs of noticeable inappropriate behaviour will occur (Erkert, 2004, p. 8-9).

Martínek (2015) defines following types of aggression typical for a school environment:

- physical, active direct - beating and humaliation of a victim, physical strenght, dominance of the attacker over the victim,

- physical, active indirect - hiring another person to hurt the victim. The original aggressor does not participate in the aggression, he thinks of ways of hurting and then watches it,

- physical, passive direct - the aggressor keeps the victim physically from achieving the goal (intentional destruction of assigned tasks and teaching aids),

- physical, passive, indirect - the aggressor refuses to help or favour the victim (assistance to the disabled),

- verbal, active direct - insults, verbal humiliation, vulgarisms. The individuals find their behaviour normal,

- verbal, active indirect - intentional incorrect prompting in the class, mocking and slandering that harms others,

- verbal, passive direct - refusal to respond to victim's questions, greetings, the victim seems not to exist,

- verbal, passive indirect - not to protect and defend unfairly criticized and punished individuals.

Specific form of aggressive behaviour often occurring in a school environment is bullying. The document Methodological Guidance of Ministry of Education of Slovak Republic No. 7/2006-R for prevention and solving of pupils' bullying at schools and school facilities defines the nature of bullying as a long-term, repeated and intentional harming with the goal to gain superiority. Its characteristic feature is power disproportion in that the victim is by some reason defenceless. According to Emmerová (2014, p. 121) bullying is any pupils' behaviour with the goal to hurt other pupil or pupils or endangering or intimidation of them. It is a targeted and repeated violence towards pupils that are not able to defend themselves. Bullying occurs in various forms. It occurs mostly during the breaks, on toilets and in changing rooms or in places without the supervision of a pedagogue. It can also occur on the way to school or home. According to the Methodical Guidance of Ministry 
of Education of Slovak Republic No. 7/2006-R bullying occurs in a direct way in the form of physical attacks, offensive nicknames, abuse names, ridicule, tough commands to do something against the victim's own will, stealing of things etc.

Tóthová-Šimčáková (2006, p. 14) speaks about following basic characteristics of bullying:

1. clear intention to hurt somebody else (physically, mentally) - beating, pushing, stealing of money and things, hiding and destruction of things, ridicule, scolding, exclusion from the company of others etc.,

2. the attacker can be one child or a group of children (asymmetric aggression),

3. incidents are repeated (one-time action is not considered bullying),

4. power disproportion between the attacker and the victim - dominance or victim's defencelessness can be real or apparent, in the area of physical power or aggressiveness, in the personal individual's power or in the dominance of a group.

There are two kinds of participants in bullying (aggressor, victim). Aggressor is the one who bullies. It is usually a boy but also girl aggressors occur. Aggressors are usually physically strong individuals but it happens that the lack of physical power is compensated by intelligence. An excessive desire for power and strong effort to dominate are typical for aggressors, they are self-confident and not anxious. The victim is a child that is the target of bullying. It can be any child but it is mostly an individual that is lonely, insecure, quiet, with low self-confidence, with problems with self-assertiveness, mostly new in the group. An aggressor often chooses children with a mental or physical handicap, markedly different children suffering e.g. from obesity, clumsiness. Since bullying is one of the most serious negative phenomena at schools it is important to prevent it and to apply effective prevention, in which school plays an important role. Bullying is not only the issue of the aggressor and the victim, it also concerns the witnesses of bullying who can play a positive but also a negative role. Alarming is the fact that the age of an aggressor decreases, the number of bullying increases and the brutality has also a growing tendency (Hroncová, Emmerová, \& Hronec, 2014, p. 123-124).

Hroncová (2004, p. 134) defines five development stages of bullying:

1. birth of ostracism,

2. physical aggression and intensification of manipulation,

3. creation of a core,

4. the majority accepts the norms of the aggressors,

5. totalism or perfect bullying.

Birth of ostracism - if we do not work purposefully with relationships in a group, it comes to this situation. Educationalists, who do not know the composition of a group and are not interested in the relationships between the members of the group, are not able to find out which members of the group are popular and which ones are at the margins of the group. They are not able to notice the problems in time, intervene and rectify 
the situation. Everybody who gets to the margins of a group suffers from milder forms of psychological violence. The group does not accept them. The others make fun of them at their expenses. They are often individuals that are different. We call this stage ostracism. It is an early form of bullying and contains the risk of a negative development. Physical aggression and intensification of manipulation - the most vulnerable members of a group serve in hard situations as a vent for the anger of others. In this stage it comes to a change, milder physical aggression appears and it comes to an intensification of manipulation. The further development depends on the extent of positive orientation of the group and on the pupils' attitude to bullying. If there are friendly relationships between the members, positive moral values prevail and the members have negative attitude to violence, it is assumed that the attempts to bully will be thwarted.

Creation of a core - if the individuals with a strong character do not stand up for the weaker pupils and so do not stop the aggressors, the aggressors will create an aggressive core within the group. Then the members start to cooperate systematically and to develop different forms of bullying. Here comes the crucial moment when it is decided if the initial stage of bullying will develop into an advanced stage.

Acceptance of aggressors' norms - it is characteristic for this stage that the activity of the aggressors' core continues without disturbance because a strong positive subgroup was not created. The norms of aggressors are accepted by the majority of the group and they become unwritten rules. In this stage we can observe that also equable and decent pupils start to behave with cruelty and participate actively in bullying of other pupils.

Totalism - perfect bullying - it is the final stage when norms and rules of aggressors are accepted or respected by all the members of the group. It comes to exploitation. The group is divided into two parts: slave masters and slaves. The slave masters have the power. The proof of their power is that they can do what they want with the victims that are not able to defend themselves. In this stage all that is left of humanity is gone. The ideology of violence is adopted where there is no compassion shown in suffering or sense of guilt.

Bullying in a school environment leaves many negative consequences on its participants. According to Križo, Smiková and Turošíková (2014) they are as follows:

1. Psychological consequences: fear, mood and sleep disorders, feeling of exhaustion and consequent worsening of school results, sadness.

2. Physical consequences: complete exhaustion of organism leading to the rise of psychosomatic diseases (alergy, diabetes, asthma).

3. Social consequences: negative relation to school even aversion, truancy, worsened ability of common communication and of making and maintaining of social contacts.

\section{Possibilities of prevention of aggressive behaviour and bullying}

With the growth of deviant forms of behaviour by pupils, from small thefts to more serious socio-pathological phenomena, the need for effective prevention is also growing; 
it means primary prevention in the first place, but regarding the widespread occurrence of such behaviour, secondary prevention is also needed (Emmerová, 2011, p. 21).

Primary prevention (universal, general) concerns the general conditions of preventing the rise of socio-pathological phenomena. It is realised by family, after-school facilities, mass media and other institutions (Emmerová, 2011, p. 87-88). It is focused on the pupils that do not show problems with deviant behaviour, it serves for formation of values, healthy lifestyle and positive interpersonal relationships. The goal of prevention should be creation of such conditions that offer the children healthy physical, psychological and social development. Preventive programmes oriented on constructive conflict solving, dealing with difficult situations, development of social skills, also contribute to the primary prevention. (e.g. "Heart on Sleeve", "Oli's story" etc.) (Hroncová, Emmerová, \& Hronec, 2014, p. 128-130).

Secondary prevention (selective, directed) is oriented on endangered groups. Its goal is to bring an individual back to the original state and to check him systematically because of the risk of repeated failure. Its realisation belongs to the scope of activity of psychological, medical, social and educational institutions (Emmerová, 2011, p. 87-88). Secondary prevention represents goal-directed work with children and young people and its essence is to prevent establishment of undesirable behaviour manifestations, remove the reasons that caused the inappropriate behaviour and catch the manifestations of this behaviour in its early stage (Hroncová, Emmerová, \& Hronec, 2014, p. 128-130).

Tertiary prevention (indicated) is focused on preventing the worsening of the state and relapse of undesirable behaviour. It is a part of long-term social rehabilitation process and is carried out on a professional level via specialised staff of social rehabilitation facilities (Emmerová, 2011, p. 87-88). The goal of tertiary prevention is to prevent worsening of the state and relapse of undesirable behaviour. It includes therapeutic and group programmes, helplines etc. (Hroncová, Emmerová, \& Hronec, 2014, p. 128-130). According to Ihnacík (2013, p. 8-21) aggression prevention at schools is realized as follows:

- social competences and the practice thereof from the position of psychologists, teachers, peer pupils in different spheres (coping with values and norms, healthy lifestyle in a school environment and in the whole society),

- trainings and courses of social competences with educational and cognitive elements in connection with extensive collective system of preparation for work, life and qualification improvement,

- adequat behaviour teaching techniques within social situations, respecting the development aspects of children, young people and techniques of mutual respect and acceptance in a school environment which represents highly effective means of aggression prevention at schools,

- by individuals and groups with violent and aggressive manifestations of behaviour in centres of pedagogical-psychological consultancy and prevention,

- the most effective forms include consultancy psychological services and with cooperation with parents and teachers also psychotherapeutical interventions, 
- very important is the work of pedagogues and psychologists in the centres of pedagogical-psychological consultancy and prevention that work in terms of prevention with peer groups (pupils, students) oriented on healthy lifestyle and elimination of aggression through supervision,

- also the media contributes to a large extent to prevention of aggression which has, from the point of view of access of children and young people to informationcommunication technologies, often inappropriate influence,

- school is an institution that influences primarily, from the point of view of impact, the aggression and violent behaviour of children and young people. In the first stage of aggressiveness it can effectively influence the elimination of aggressiveness, its directing and change of behaviour.

Aggressive behaviour belongs to serious socio-pathological phenomena. Specialists point out the rapid increase of this problem in a school environment. Therefore it is necessary that the school participates in effective prevention of inappropriate behaviour. For effective prevention it is necessary:

- To analyse the occurrence of socio-pathological phenomena and focus primarily on preventing it (constant work of the class teacher, monitoring in a school environment etc.). Important in a school environment is also prognosis of occurrence and choice of the right forms and methods in the area of (primary, secondary) prevention.

- Effective prevention should clarify, explain and offer alternatives and not intimidate and command.

- Within the primary prevention, the systematic and goal-directed work that cannot be substituted by one-time activities, is also important.

- To use different forms of prevention: preventive programmes and projects, an educational process in subjects where the curriculum allows it (ethical education, social studies), using ICT, education in healthy lifestyle (Emmerová, 2010, p. 57).

Our attitude to aggressive behaviour of children and young people cannot be indifferent. Possibilities of prevention of aggressiveness are as follows:

1. Information - if pupils get necessary information (knowledge) about aggressiveness, they are able to understand this phenomenon and to deal with it by learning.

2. Positive example - children adopt behavioural patterns in their immediate environment (family, school).

3. Appropriate education methods - in family, at school and in a wider social environment.

4. Affective learning - methods that put the emphasis on emotions, knowledge, interpersonal relationships as a basis for strenghtening and learning of behaviour.

5. Self-control - to learn to control aggressivenes and to use it in a right way (Kopčanová, 2004, p. 8). 
Kariková (2001) presents these recommendations for pedagogues in case of bullying at schools:

1. The basic principle that must be valid for everybody without exception from the first school day is contained in the statement "We are a school where bullying and blackmailing is not tolerated". The whole educational influence of the school must be based on this statement.

2. Pupils and parents should be informed that bullying is a crime.

3. The school should create such conditions that the bullied pupils would not be afraid to confide in pedagogues.

4. To secure supervision in those places where bullying mostly occurs, e.g. toilets, changing rooms etc.

Ministry of Education of Slovak Republic made a Methodological Guidance No. 7/2006$\mathrm{R}$ that is oriented on prevention and dealing with bullying of pupils at schools and in school facilities. Within effective prevention by the preparation and realization of wholeschool-strategy, it recommends:

- to create a positive atmosphere at school,

- to create a close cooperation with pupils, between school staff, parents,

- to determine clearly the rules of behaviour in the school policy, including sanctions for breaking them, to keep written records about solving particular cases of bullying,

- to strenghten the pedagogical supervision during breaks and after school,

- to raise the awareness of pedagogical staff, to organize lectures with specialists in given field,

- to inform pedagogues, pupils and parents about what to do if they hear about a case of bullying,

- to provide the class teachers, prevention coordinators and guidance counselor with the education in the area of prevention of bullying,

- to cooperate with the people from centres of educational and psychological prevention,

- to define the reporting obligation for pedagogical and non-pedagogical staff in the school policy.

The primary prevention at schools is realized in different forms such as various preventive work projects. Their realization is focused on preventing the socio-pathological phenomena. The prevention of aggressiveness and bullying is oriented primarily on constructive solving of conflicts and on development of social skills, dealing with mental strain etc. It includes projects such as "Heart on a Sleeve", "Way to Emotional Maturity", "We Know That...", "Behave Normally", Peer Programme of Universal Prevention and other PEER programmes etc. 


\section{Conclusion}

Aggressive behaviour and bullying is nowadays a widespread socio-pathological phenomenon pointed to by teachers, parents but also the wide society. It occurs not only at schools between the pupils but also between pupils and teachers, friends, and what is startling also children towards their parents. The experts point out the seriousness and necessity of prevention of these phenomena because it is easier to prevent such problems than to solve often even a critical situation that has, in many cases, lifelong consequences. The best prevention is a positive and functioning family environment with positive emotional relationships between children and their parents in that children are raised by their parents and not "by the street". The school can, with good cooperation with parents, then build on these "good foundations" of right upbringing. According to Emmerová (2011) school belongs to important socialisation and educational factors. It is very important that the school carries out preventive activities focused on the area of awareness and actions of pupils which could help prevent the emergence and occurrence of problematic behaviour. The rising in such behaviour by pupils at primary and secondary schools requires an effective and permanent realization of prevention in schools in that it is mainly the primary prevention.

\section{References}

Emmerová, I. (2010). Agresívne správanie žiakov - prevencia a riešenie v školskom prostredí [Aggressive Behaviour of Pupils - Prevention and Solution in School Environment]. Mládež a spoločnost' [Youth and Society], 15(1), 57.

Emmerová, I. (2011). Aktuálne otázky prevencie problémového správania u žiakov $\checkmark$ školskom prostredí [Current Questions on Prevention of Problem Behaviour of Students in School Environment]. Banská Bystrica: Faculty of Education, Matej Bel University.

Emmerová, I. (2013). Agresivita a šikanovanie u žiakov základných a stredných škôl [Aggressivity and Bullying in Elementary and Secondary School Pupils]. Vychovávatel' [Educator], 61(7-8), 2-7.

Erkert, A. (2004). Hry pro usměrňování agresivity [Games for Directing Aggressivity]. Prague: Portál.

Határ, C. (2007). Agresia žiakov očami sociálneho pedagóga [Pupils' Aggression Through the Eyes of a Social Pedagogue]. Nitra: Constantine the Philosopher University in Nitra.

Hroncová, J. (2004). Sociálna patológia [Social Pathology]. Banská Bystrica: Faculty of Education, Matej Bel University. 
Hroncová, J., Emmerová, I., \& Hronec, M. (2014). Sociálna patológia pre sociálnych pedagógov [Social Pathology for Social Pedagogues]. Banská Bystrica: Belianum.

Ihnacík, J. (2013). Koordinátor prevencie závislostí sociálno-patologických javov [Coordinator of Prevention of the Dependency of Socio-Pathological Phenomena]. Bratislava: Metodicko-pedagogické centrum [Methodological and Pedagogical Centre].

Janderková, D. (2010). Slovník základních pojmů z pedagogiky, psychologie a metodologie [A Glossary of Basic Terms of Pedagogy, Psychology and Methodology]. Brno: Mendel University in Brno.

Kaleja, M. (2013). Základy etopedie [Basics of Etopedy]. Ostrava: University of Ostrava.

Kariková, S. (2001). Základy patopsychológie detí a mládeže [Basics of Psychopathology of Children and Youth]. Banská Bystrica: Faculty of Education, Matej Bel University.

Kopčanová, D. (2004). Význam prevencie agresívneho správania u detí a mladistvých [The Importance of Preventing Aggressive Behavior in Children and Adolescents]. Vychovávatel'[Educator], 1(6), 8.

Križo, V., Smiková, E., \& Turošíková, A. (2014). Šikanovanie v škole [Bullying in School]. Bratislava: Raabe.

Kunák, S. (2007). Vybrané možnosti primárnej prevencie negatívnych vplyvov na deti a mládež [Selected Possibilities of Primary Prevention of Negative Influence on Children and Youth]. Bratislava: Iris.

Lovaš, L. (2010). Agresia a násilie: psychológia ludskej agresie a jej podoby v domácom prostredí, v škole, v práci, vo väzniciach a v športe [Aggression and Violence: Psychology of Human aggression and Its Forms in Domestic Environment, in School, at Work, in Prisons and in Sport]. Bratislava: Ikar.

Martínek, Z. (2015). Agresivita a kriminalita školní mládeže [Aggression and Criminality in School Children]. Prague: Grada Publishing.

Metodické usmernenie č. 7/2006-R k prevencii a riešeniu šikanovania žiakov v školách a školských zariadeniach [Methodological Guidance No. 7/2006-R for prevention and solving of pupils' bullying at schools and school facilities]. (2006). Retrieved from https:// www.minedu.sk/data/att/571.pdf

Miňhová, J., \& Mrázová, E. (1989). Vybrané kapitoly ze speciální pedagogiky [Selected Chapters of Special Education]. Ústí nad Labem: Faculty of Education. 
Smernica č. 36/2018 k prevencii a riešeniu šikanovania detí a žiakov v školách a školských zariadeniach [Directive No. 36/2018 for the prevention and resolution of the bullying of children and pupils in schools and educational establishments]. (2018).

Šimegová, M. (2007). Šikanovanie v školskom prostredí [Bullying in Schooling Environment]. Banská Bystrica: Faculty of Education, Matej Bel University.

Tinka, J. (2010). Agresivita a šikana v České republice z pohledu středoškolské mládeže [Aggression and Bullying in the Czech Republic from the Perspective of Secondary School Pupils]. Mládež a spoločnost' [Youth and Society], 16(2), 65-70.

Tóthová-Šimčáková, M. (2006). Prevencia a eliminácia šikanovania [Prevention and Elimination of Bullying]. Sociálna prevencia [Social Prevention], 1(1), 14-15.

\section{Author}

PhDr. Katarína Cimprichová Gežová, PhD.

Faculty of Education, Matej Bel University

Department of Pedagogy

Ružová 13, 97411 Banská Bystrica, Slovak Republic

katarina.gezova@umb.sk 